\title{
CONDITIONS REQUIRING THE USE OF AUTOMATIC GAGES IN OBTAINING RECORDS OF STREAM FLOW. ${ }^{1}$
}

\author{
By C. H. Pierce.
}

The summary of field operations of the division of surface waters of the United States Geological Survey for 1913-14 contains a statement showing the number of gaging stations maintained by the Survey and the types of gages used. The total number of stations so maintained was 1,741 , of which 325 stations were reported as equipped with automatic gages.

The necessity for automatic gages has long been recognized, but probably the first systematic study by which the errors incident to the method of using two gage heights a day could be determined and compared with the errors due to incorrect methods of handling the automatic-gage records was started by the engineers of the Geological Survey in December, 1912. This study was carried on during the year 1913, and comparisons of methods were made for a number of gaging stations in different parts of the United States. One of the results of the investigation was the discovery that at a few stations better results would have been obtained with two readings a day than with continuous gage-height records not correctly used, as in the use of two readings a day the errors were largely compensating, whereas the incorrect method introduced errors of a cumulative nature. At other stations equipped with recording gages it was found that two readings a day would have been enough to give results sufficiently accurate for all practical purposes, although greater refinement was obtained by the use of the recording gage. These discoveries must not be interpreted as arguments against the use of automatic gages. They are mentioned to show the necessity of first determining whether the conditions require the use of an automatic gage, and later, if the gage is installed, of making sure that the accuracy of the method used in computing the discharge is comparable with the accuracy of the gage-height data.

The problem is how to determine whether the conditions are such that two readings a day from an ordinary staff or chain gage will give satisfactory results and what different conditions will warrant the

1 Presented at the conference of engineers of the water-resources branch, United States Geological Survey, Washington, D. C., Dec. 8, 1914. 
installation of an automatic gage. Also, how to determine at the time of establishing the station the type of gage needed.

The conditions which require the use of automatic gages may be summarized as follows:

1. Regulation of the stream by power developments.

2. Operation of canals and ditches delivering water for irrigation.

3. Fluctuations due to variation in run-off under natural conditions (a) caused by rain and $(b)$ caused by melting ice and snow.

4. Inaccessibility of gaging station or lack of reliable observer.

5. Continuous record needed for legal purposes.

6. Human fallibility of most gage observers.

The great increase in the number of water-power plants during the last 10 years has affected many streams. The operation of some of these plants gives nearly complete regulation of the stream at all stages; that of others affects only the low-water flow. An examination of the hydrograph of Quaboag River at West Brimfield, Mass. (fig. $25, A$ ), which is illustrative of a type of hydrograph obtained under very complete power regulation, should convince one of the impossibility of making reliable estimates of discharge from gage readings obtained twice a day at this station. For streams of this class there can be no question regarding the necessity of using automatic gages, whatever the purpose for which the data are required. This stream has a large natural storage in ponds and lakes and would not be subject to severe fluctuation under natural conditions.

A partly regulated stream is illustrated by the hydrographs of Swift River at West Ware, Mass., shown in figure 25, $B$. This stream is also in the central part of Massachusetts and its natural conditions are similar to those of Quaboag River. From the hydrographs it may be seen that for a mean discharge below 100 second-feet the regulation is such as to change the natural conditions of flow entirely and would make gage heights taken twice a day of little value. For a mean discharge of 200 second-feet the power effect is slight, the peaks on the gage-height hydrograph being nearly submerged. Above 300 second-feet there appears to be no appreciable effect from power operation. For this particular stream the data obtained without the use of an automatio gage would probably be classed as "good" for about three months of the year, "fair" for about four months, and decidedly "poor" for the remaining five months. Any use of the data requiring a knowledge of the low-water flow would of course call for continuous gage-height records.

In order to insure the highest efficiency in the operation of an irrigation system, it is necessary to study the distribution of the water from the time of diversion from its natural course until it is applied to the soil. Continuous records of flow at various points on a canal are the only means of determining the amount of seepage losses. 
品

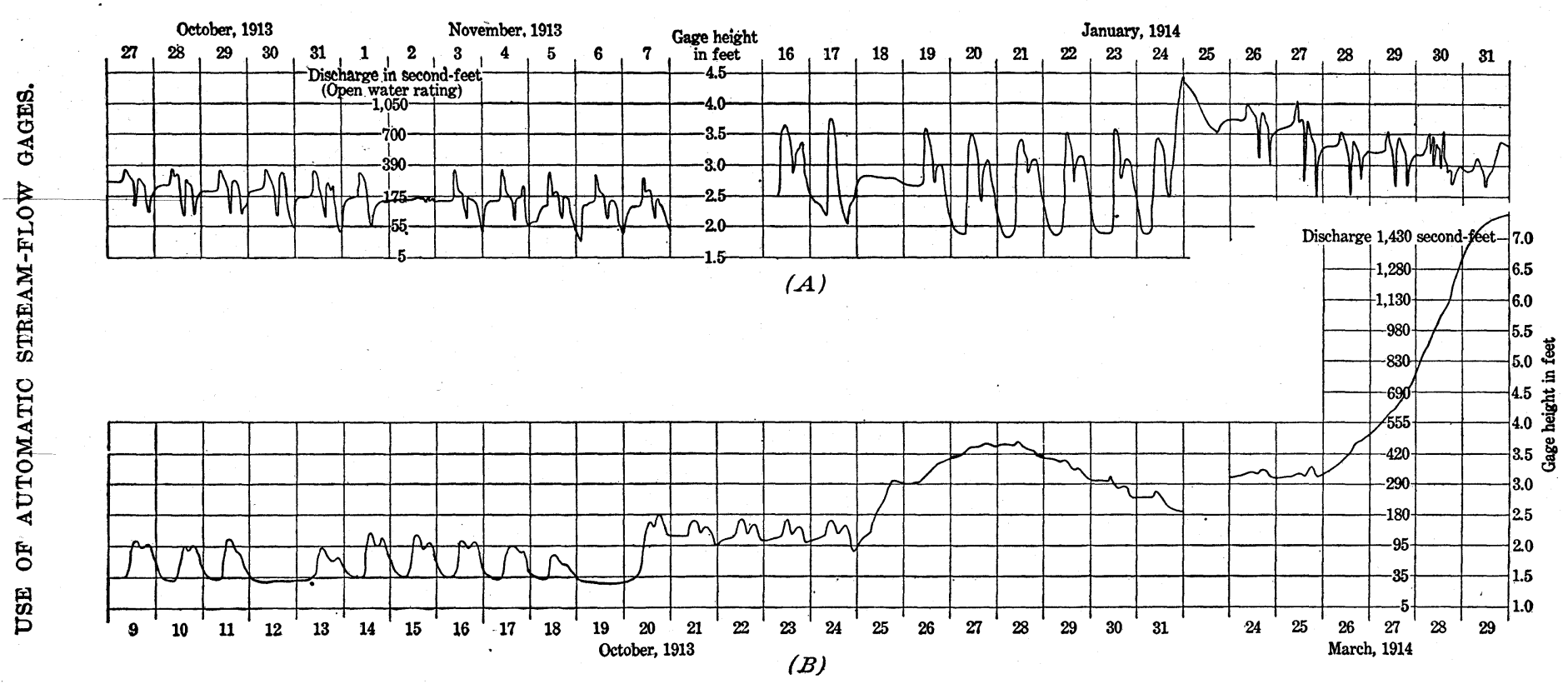

FIGURE 25.-Automatic-gage records: $A$, Quabnag River at West Brimfield, Mass.; $B$, Swift River at West Ware, Mass. 
These losses, though apparently insignificant, may prove after investigation to be serious enough to make the lining of the canal a paying investment. Another feature of the operation of an irrigation system is the division of water, and it is generally true that a division satisfactory to all parties must be based on continuous automatic-gage records.

An example of violent fluctuation caused by rainfall is shown in figure 26, which is a gage-height hydrograph of the North Fork of Wailua River, on the island of Kauai, Territory of Hawaii. This hydrograph shows a difference in stage during one day which corresponds to 300 per cent of the mean discharge for the day. The .

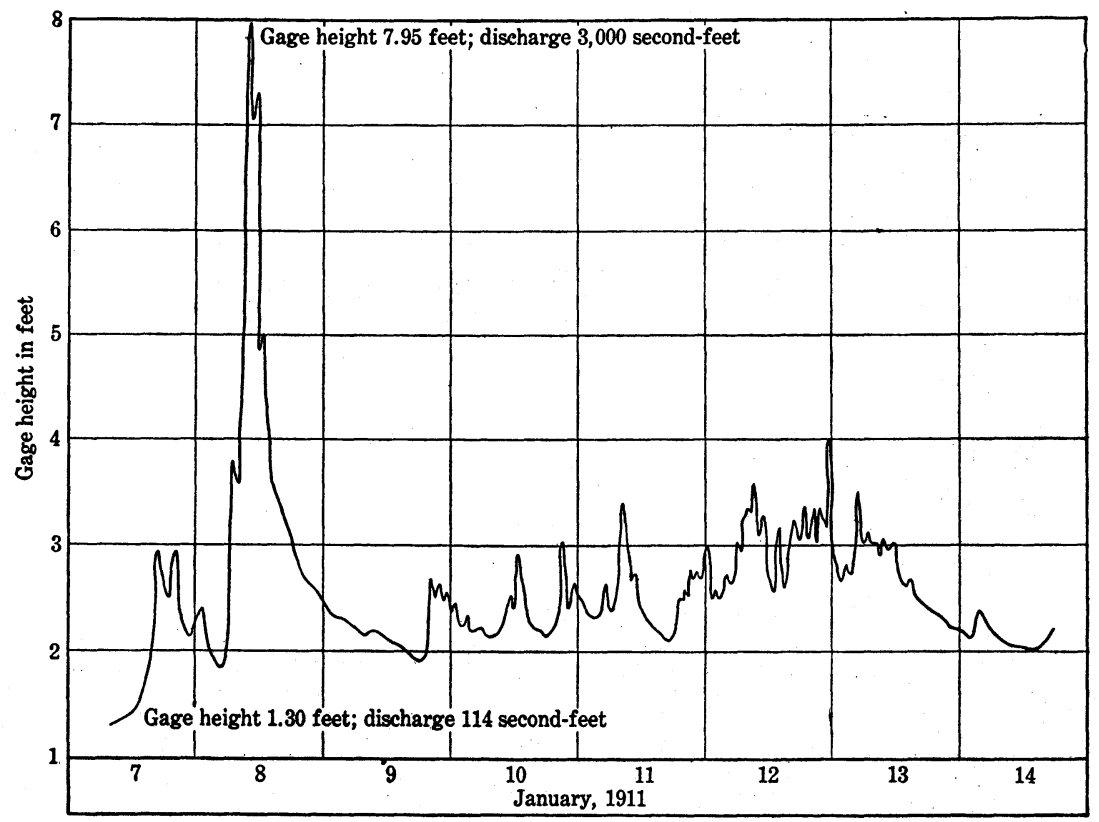

FIGURE 26.-Automatic-gage record, North Fork of Wailua River near Lihue, Kauai, Hawaii.

general appearance of the hydrograph should convince one at a glance that reading gage heights twice a day at this station would be of little value. Fluctuations due to rainfall are more uncertain than those due to other causes, for no one can successfully predict when they will be likely to occur. The necessity of using automatic gages on streams where accurate flood data are required is evident. The peak of the flood may be of only a few minutes' duration and therefore likely to be missed if observations are limited to two or even more than two readings a day taken during waking hours. A knowledge of the absolute maximum and its duration may be all important in connection with flood prevention. 
Streams fed by melting ice and snow are subject to large diurnal fluctuations which occur with considerable regularity. The gageheight hydrograph of Kings River near Sanger, Cal. (fig. 27), gives a good illustration of this type of fluctuation. This hydrograph shows that in May the difference in stage during the day averages about 30 per cent of the mean discharge for the day. For periods later in the season the flow of this type of stream is likely to be more uniform, so that it might be passible to obtain fair results during a part of the year from readings twice a day. Many streams in the mountains of California, Colorado, and other Western States are affected by this condition. As the waters of those streams are usually of value for

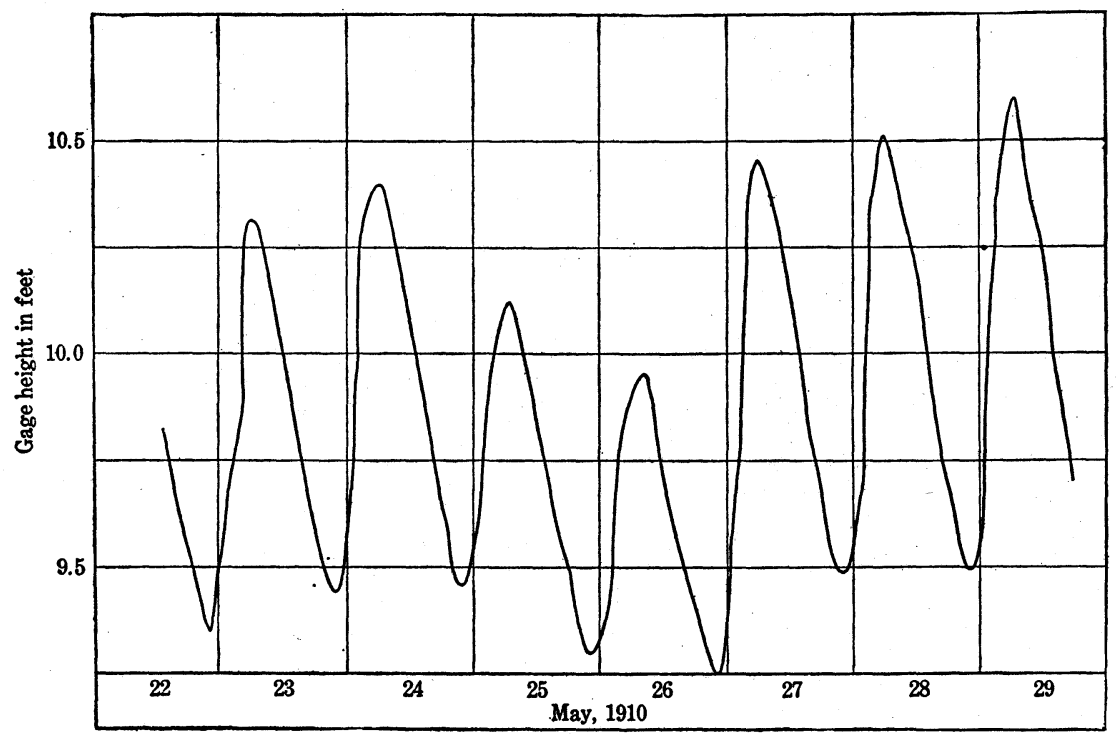

FigUhe 27.-Automatic-gage record, Kings River near Sanger, Cal.

irrigation and frequently conflicting interests present priority claims, it may be seen that the data should be based on continuous records.

Probably many stations have been established and are now being maintained at places where the strongest argument in favor of those particular sites was their convenience to the observers. An observer must be had, and if one could not be found near the desirable station site, then the station must be established at a site where an observer is available. The difficulties of rating the station and the effects of ice and $\log$ jams were subordinated to accessibility, for the gage reader was the first and principal consideration. However, the human equation of the observer need not have so great an influence at the present time, for at least two types of automatic gages now on the market can easily be installed so as to give a continuous gage-height record 
for three months or more without any visit from the observer. Very often data are desired at places so remote and inaccessible that the only practicable means of obtaining the records is by the use of automatic gages.

For legal purposes there is certainly an advantage in having automatic-gage records that can be produced in court and attested as the original measurements obtained automatically by the rise and fall of the water surface. An automatic gage is not likely to be influenced by interested parties without the knowledge of the engineer in charge of the station.

Details of the human fallibility of most gage observers and the entire unreliability of some would fill a volume. Many times the observer "honestly" thinks he knows about how high the water is without visiting the gage, and so puts down in his book some figures which are later given much consideration by the office engineer. Often the observer, if he is a new one, does not understand the exactness of the methods, and thinks a tenth or so one way or the other will not matter much, especially as the gage heights often vary considerably between readings. Two sets of gage readings obtained at different 'gages on Lake George during 1913 (fig. 28) illustrate this point and show the need of check readings or else a recording gage.

Whether or not the installation of a recording gage will be warranted at a particular station is a question to be decided from the needs and requirements of that individual station. No general rule can be formulated. It is possible, however, to distinguish between stations established for special studies and base stations established for the collection of general statistical information. The former are likely to be maintained for short periods only and may be of value only for the special investigation; the latter are likely to furnish the data on which estimates and comparisons at different places and for many purposes will be based. It should be remembered that the future value of the records obtained at these base stations will depend largely on the location of the station and the gage installation.

With a good general knowledge of the stream, including character of the drainage area, natural storage, and present or prospective power developments, and bearing in mind the object for which the station is to be established, the engineer should be able to arrive at a fairly definite decision as to the need for an automatic gage. When in doubt as to the effect of power regulation or the magnitude of any fluctuation it would be advisable to set up a portable automatic gage and study the action of the stream for a few days. The portable gage should be placed at the edge of the stream as near as 


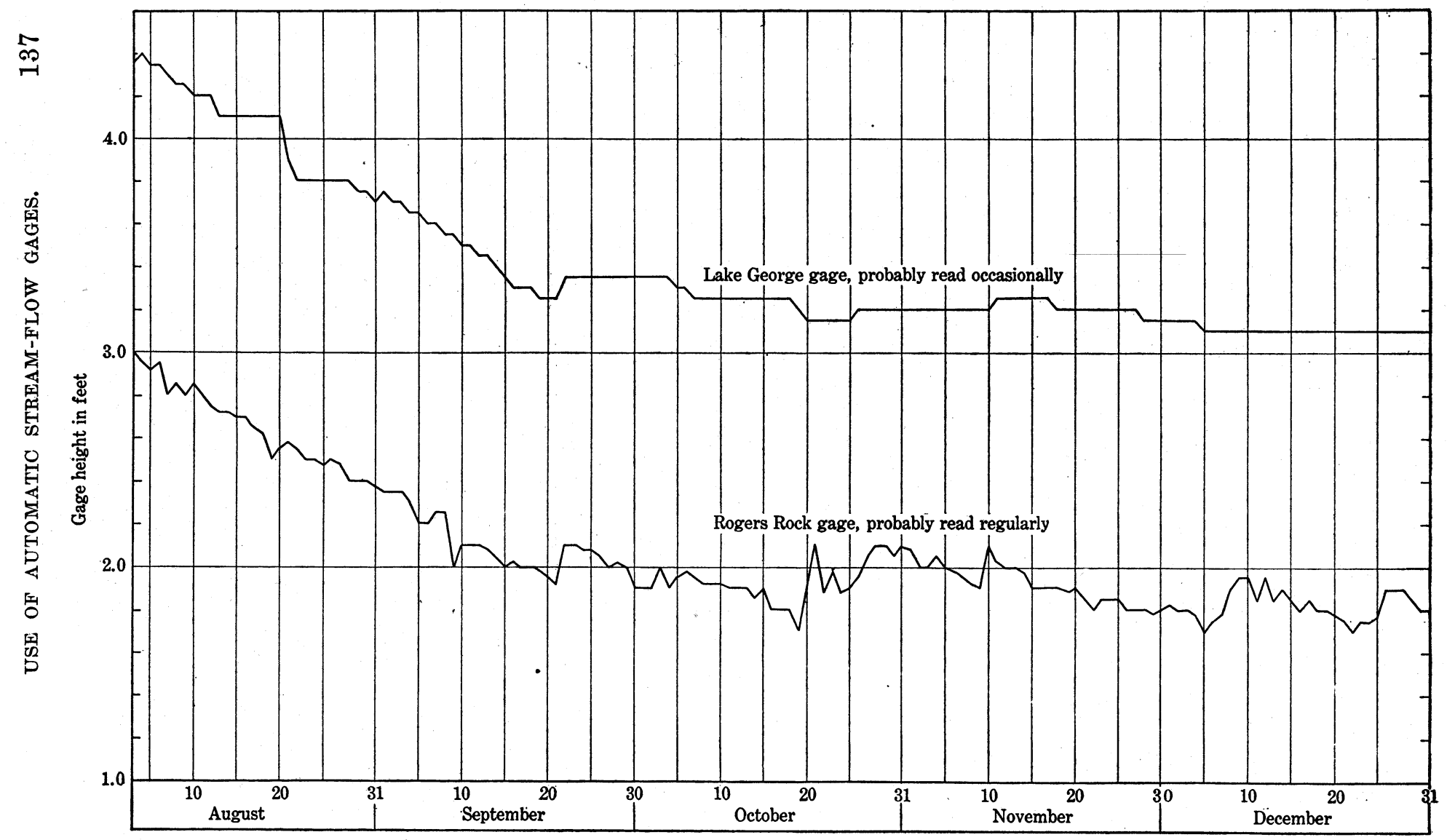

FIGURE 28.-Comparative hydrographs of lake elevations recorded by different observers: Lake George at Lake George and at Rogers Rock, N. Y. 
possible to the exact site decided upon for the station, and the data obtained by it should be referred to a permanent bench mark. If possible, two or more runs should be made, one at low stage and the others at intermediate stages. Discharge measurements should be obtained so that an approximate relation between change in gage height and change in discharge may be determined. The use of a portable gage for a preliminary study may possibly be the means of saving many dollars that would be required for an expensive gage installation. On the other hand, such a study may show the need for an automatic gage and decide the question by positive proof rather than by personal opinion. Figure 29 shows a gage-height hydrograph obtained by the use of a portable recording gage on Ausable River at Ausable Forks, N. Y. Owing to regulation by paper mills a short distance above the station the reading of gage heights twice

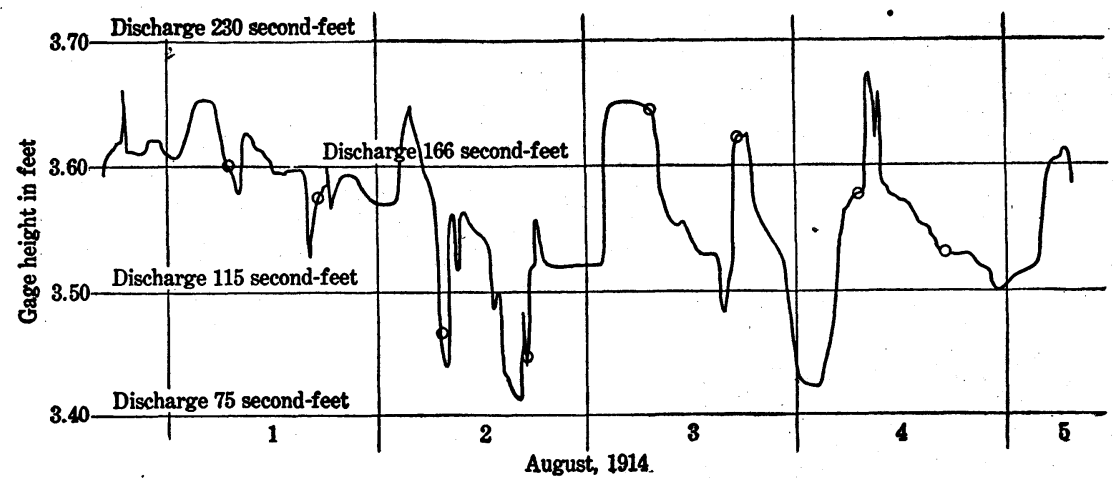

Figure 29.-Portable-gage record, Ausable River at Ausable Forks, N. Y.

a day was thought to be insufficient for the determination of discharge, and an automatic gage was considered necessary. In order to obtain positive proof of the need for an automatic gage, a portable gage was set up by the side of the chain gage and continuous records were obtained from July 10 to October 4. The data for August and September were computed by the method of reading gage heights at 7 a. m. and 5 p. m. and also on the basis of hourly discharge. For August the readings twice a day gave a monthly mean error of +3.5 per cent; for September, -0.5 per cent. Although some large errors occurred in the values for individual days, the monthly means were considered sufficiently accurate for present requirements, and the installation of an automatio gage at that station has been indefinitely postponed. The only expense item chargeable to the installation and maintenance of the portable gage consisted of 59 cents expressage. 
The hydrograph shown in figure 30 was obtained by the use of a portable gage on Winooski River at Montpelier, Vt. Several runs were made at different stages, and the data obtained showed conclusively that an automatic gage was necessary. Various makes of gages are adapted to these preliminary studies, the main requirements being compactness and simplicity of operation. This study by means of a portable gage may also be of assistance in determining the type of automatic gage to be installed if it is found that one is needed.

By a wise selection of gages and proper installation and by grouping instruments of the same type so that the needs of several can be cared for on the same inspection trip, in order to avoid the necessity of the engineer making special trips to remote points, the cost of maintaining automatic-gage stations should not greatly exceed the cost of properly maintaining the same stations equipped with staff or chain

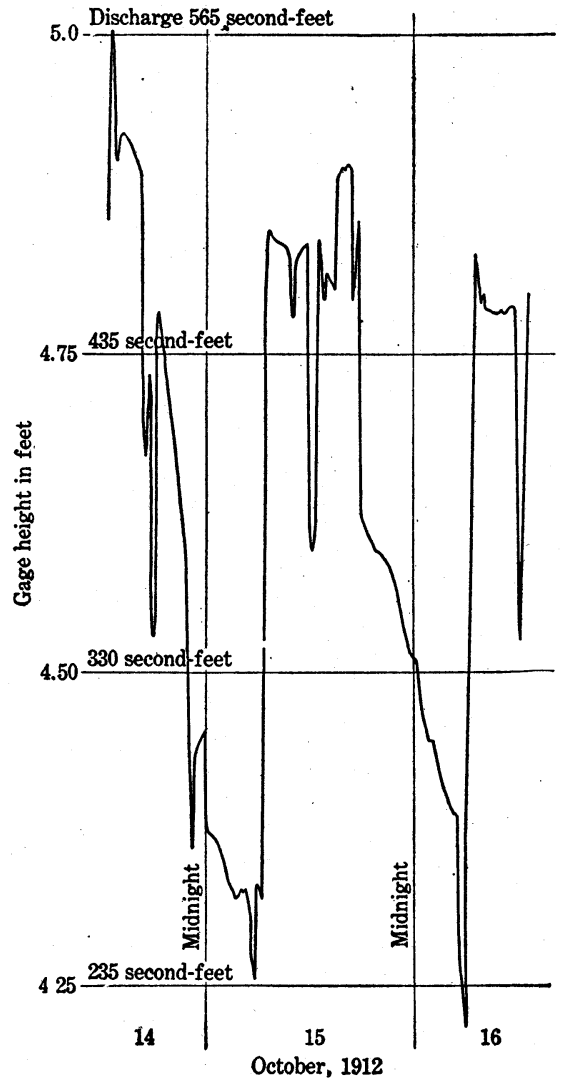

FIGURE 30.-Portable-gage record; Winooski River at Montpelier, Vt.

gages only. The necessity for the right kind of installation must be emphasized, however, especially in those parts of the country where the winters are severe. 
